\title{
In the Midst of Ambivalences in Islam
}

Because of recent events in the 'Islamic world' and the rise of the so-called 'Islamic State in Iraq and Syria', distinct, even partially contradictory positions have emerged within Islam more clearly than before. It is certainly no exaggeration to say that at this point in no other area do the ambivalences stand out so much as in Islam. The antinomy between the inhuman cruelties by those who allegedly appeal to 'true Islam' and the denial of any connection of these deeds with Islam by the majority of Muslims show the great ambivalences that are present within Islam, which is preferably viewed as a monolithic block.

The fact that Muslims even represent different positions on the legitimation of violence by religion shows that there is a fundamental ambivalence in various areas of Islam. Because it is impossible to present all these areas in this essay, it seems more appropriate to approach the ambivalences in Islam from three perspectives. These perspectives are of major importance in Islamic theology and bring Islamic theology into connection with current events around Islam. The internal perspective, the interreligious perspective, and the personal perspective discussed below will provide insight into ambivalence regarding the Qur'an, other religions, and religiosity within Islam.

\section{The Internal Perspective: Between Text and Context}

In distinction from Christianity, Islam has no structure like the church has and thus does not have a "priestly-clerical structure" (Casanova, 2009, 48) either, as found in the Catholic tradition. Accordingly, there is no fixing or promulgation of doctrine by a specific institution "as revealed by God" (Rahner, 1959, 439). But this does not mean that there is no core content to which many Muslims adhere; it only means that this content cannot be fixed by church-like institutions. This is also clearly evident in E. Muammar's essay on dogma, which was written from a Muslim perspective. We read:

\footnotetext{
With the political events after the death of Muhammad, very different ways arose among Muslims for dealing with questions of faith. In particular, the encounter with various religions, cultures, and philosophical traditions was decisive for the development of Islamic dogma. Given this plurality, Islamic scholars strove to establish the principles of the faith according to its original meanings so that they could establish a uniform faith for Muslims. (Muammer, 2013, 137)
}

○ OpenAccess. ( 2022 Zekirija Sejdini, published by De Gruyter. (cc) BY-NC-ND This work is licensed under the Creative Commons Attribution-NonCommercial-NoDerivatives 4.0 International License. 
It thus becomes clear that doctrine in Islam generally reflected the opinions of scholars who could only appeal to their own knowledge and not to institutions whose authority could be derived from a holy text.

Nevertheless, the reality - as is so often the case - is different on this point as well. The lack of an institution for the development of Islamic doctrine did not stand in the way of the formation of dogma-like doctrines, but this development became the task of individuals. Thus, there are various doctrines that were viewed as dogmas over the course of time without being designated as such. For example, in Sunni Islam, there are only four law schools and two schools of thought that are recognised, and any deviation from their teachings is often viewed as heresy (Abu-Zaid, 1996).

The most important source of Islam, the Qur'an, did not escape this process of dogmatisation either. Although the divine source of the Qur'an is undisputed in the Islamic tradition, its nature and the appropriate approach to it are subjects of controversy. On the one hand, it is a matter of faithfulness to individual passages of the Qur'an with the intention of maintaining the message's originality and to protect it from any non-divine intervention - and concomitantly to condemn any deviation from the wording of the text and the dogmatisation of any single interpretation. On the other hand, there is also the attempt to understand the Qur'an in the spirit of the times in order to keep it relevant and to allow it to have the effect it had when it was revealed.

Despite the fact that the Qur'an was not sent into a vacuum but came into existence over a period of 23 years and reflected the situation of the prophet, its first addressees, and the entire context at that time, the dogmatisation of the Qur'an prevailed in the Islamic tradition. The rise of individual disciplines in the early phase, which were to facilitate the understanding of the divine message and were subsumed under the concept of Qur'anic sciences (Krawulsky, 2006), did not succeed in bringing about a more historical-critical reading of the Qur'an. Therefore, the most recent efforts to present the historical-critical method as a lasting component of the above-mentioned Qur'anic sciences testify not only to the lack of knowledge about this method but also to the nature of the Qur'anic sciences (Körner, 2006).

The discussions on the nature of the Qur'an and the accompanying discussions on an appropriate interpretation came to a head quite early and led to two contrary positions. The renowned translator of the Qur'an, Theodor Adel Khoury, describes these positions in his commentary on the Qur'an as follows:

Because Islamic theology until now has assumed that the Prophet was inspired word for word, the question arises as to whether the Qur'an has a supramundane existence and whether it must be viewed as eternal. One school emphasised that the Word is an eternal 
attribute of God and therefore the Qur'an has to be viewed as eternal and uncreated. As the Word of God, the Qur'an exists eternally and not only in the heavenly book. The Mu'tazilites rejected this teaching in the ninth century because it could not be reconciled with strict monotheism, with the unity and uniqueness of God. (Khoury, 1990, 99)

After a number of disputes between the advocates and opponents of the view of the Qur'an as uncreated, the doctrine of the eternity of the Qur'an prevailed over the view proposed mainly by the rationalistic Mu'tazilites who viewed the Qur'an as created and thus prepared the way for the rise of an ambivalent attitude towards the Qur'anic text within the Islamic tradition, which has had far-reaching effects right up until the present.

The dominance of the doctrine of the Qur'an as uncreated in Islamic theology did not only lead to the acceptance of a perfect Qur'anic text, which was obvious anyway for faithful Muslims (Özsoy, 2006a, 154). It also had a lasting impact on the entire image of Islam. Abu-Zaid describes the far-reaching consequences of this acceptance in a very striking way in his analysis when he writes:

The belief that the Qur'an is eternal implies, for instance, that God preordained every event described in it and leads to the belief in God's absolute predestination; those who want to deny this predestination must believe the Qur'an to be created. And, to mention yet another example, he who advocates the doctrine of God's absolute unity and unicity (a central Islamic belief) and wishes to take this in its strictest sense, denies the existence of an uncreated Qur'an together with God in all eternity.... [T] he notion of eternal Qur'an leads automatically to strict adherence to the literal meaning of the text. (Abu-Zaid, 1996, 46)

Because of the literal approach to the Qur'anic text, however, the living communication between Creator and creature is suppressed and continually new interpretations of the Qur'an - which was indispensable for the vitality of the divine revelation - are inhibited. Ömer Özsoy sees the proof of the vitality and thus of the inclusion of human needs and their context in the process of the revelation of the Qur'an as embedded in the Qur'an itself (Özsoy, 2006a, 154). As one of many examples that indicate the living character of the Qur'an, Özsoy cites sura 5:101, which reads:

O YOU who have attained to faith! Do not ask about matters which, if they were to be made manifest to you (in terms of law), might cause you hardship; for, if you should ask about them while the Qur'an is being revealed, they might (indeed) be made manifest to you (as laws). (Q 5:101; for this and other quotes from the Qur'an, see Asad 2008)

According to Özsoy, this verse and others in the Qur'an (Q 2:222, 2:189, 2:217) show clearly and unambiguously that the revelation refers to human needs 
and the events of that time and responded to them. This means, therefore, that the process of revelation was influenced from outside (Özsoy, 2006a, 154).

The suppression of the vitality, the living quality, of the divine communication - which, given the fixing of the Qur'anic text in writing and the temporal distance from the time of the revelation, is difficult to reconstruct - leads to the suppression of the historicity of the Qur'anic text. Instead, a universality is alleged that sees the spirit of understanding to consist in constantly reproducing the interpretations of the early scholars. Independent interpretations that take into account the times and the context were viewed in extreme cases as dangerously close to unbelief. This is a problem that Abu-Zaid gets to the heart of when he writes:

Religious discourse is aware that religious texts are only interpretable, and the interpretation can vary according to place and time. In interpretation, however, religious discourse does not go beyond the understanding of the text found in the early legal and religion scholars; it therefore limits interpretation to law texts and excludes beforehand (the possibility of the interpretation of) doctrines or the Qur'anic stories. It denies the independent interpretation of doctrine or the religious stories, even accusing such of apostasy. (AbuZaid, 1996, 82)

If we look at the approach of some people, who use Islam to justify their violent deeds, it becomes clear that an unreflective approach to the Qur'an - which is usually manifested as an attempt to understand the Qur'an apart from the context in which it came into existence - is one of the many causes that led to the development of a theology that, in my view, contradicts the spirit of Islam. Also, at the present time, it serves to legitimise a theology of violence that has been taken over and propagated by Muslim fundamentalism to justify its own cruelties and to recruit others.

\section{The Interreligious Perspective: Between the Truth Claim and Acceptance}

The differences in opinion concerning the nature of the Qur'an are also necessarily reflected in another thematic complex in Islam that is found in the Qur'an. This includes first the attitude of the Qur'an towards other religions. Conditioned by the context in which it came into being, the Qur'an talks of other religions that could be found in Mecca and the surrounding area in the seventh century. The Qur'anic texts give special treatment to Judaism and Christianity, whose adherents are described in the Qur'an as 'People of the Book' (ahl al-kitab) ( $\mathrm{Q}$ 3:98-99, 3:65). The reason for this special treatment, the intensive explana- 
tion and the constant reference to the 'People of the Book' in the Qur'an is that Islam sees itself as part of the monotheistic tradition that is grounded, according to Islam, in the one and only God. The Qur'an presents belief in the common origin of the three religions as follows:

\footnotetext{
Say: 'We believe in God, and in that which has been bestowed from on high upon us, and that which has been bestowed upon Abraham and Ishmael and Isaac and Jacob and their descendants, and that which has been vouchsafed to Moses and Jesus, and that which has been vouchsafed to all the (other) prophets by their Sustainer: we make no distinction between any of them. And it is unto Him that we surrender ourselves.' (Q 2:136)
}

Islam's reference to Judaism and Christianity has in the meantime also become known in Europe and constitutes the centre of all contemporary interreligious encounters. The Abrahamic roots of the monotheistic religions should contribute to the highlighting of commonalities - that is the general wish. But Islam's reference to a common origin contains not only chances for improved co-existence but also a certain potential for conflict that should not be underestimated. In the end, history teaches us that the common origin of these three monotheistic religions led to conflict rather than understanding.

This becomes clear in light of the following. Because of Islam's reference to Judaism and Christianity, the Qur'an also deals with events and persons that appear in the Bible and often presents them differently from how they are presented in the Bible. The differences between the Qur'anic and the biblical stories, which should not have existed because of their common origin, are explained in the Qur'an as resulting from human meddling in the holy scriptures of Judaism and Christianity. According to the Qur'an, this meddling led to changes in the content. In the Qur'an, these changes are called distortion in some places (tahrif) (Q 2:176; 4:46; 5:13) and alteration (tabdil) elsewhere (Q 2:59). Thus, in the holy scriptures of these three religions, there are contradictory views of certain people, events, or faith principles that cannot be reconciled theologically with each other, such as the Christian doctrine of the Trinity, which is explicitly rejected in the Qur'an (Q 2:62; 5:17, 5:72-73). The different treatment of common content has certainly contributed to Islam being perceived by some Christian writers as a kind of Christian heresy (Uçar, 2009, 18f.).

The emphasis on the common origin with Judaism and Christianity on the one hand and Islam's differences from them on the other represents the foundation of the ambivalent attitude towards these religions that is reinforced by the various, partly contradictory statements on Judaism and Christianity in the Qur'an. Chronologically, there were initially many verses in the Qur'an that emphasise what the three religions share $(Q 2: 136 ; 3: 64)$ and prompt Muslims to a 
respectful relationship with Jews and Christians. The following verse is a good example:

And do not argue with the followers of earlier revelation otherwise than in a most kindly manner - unless it be such of them as are bent on evildoing - and say: 'We believe in that which has been bestowed from on high upon us, as well as that which has been bestowed upon you: for our God and your God is one and the same, and it is unto Him that we (all) surrender ourselves.' (Q 29:46)

But the language of the Qur'an about the adherents of Judaism and Christianity changed after the exodus to Medina in 622 (AD). Without going into the grounds for this change, it must be remembered that an intensification of reproaches against the Christians and the Jews can be observed in the Medinan period of revelation. Here the criticism is directed very much at the Jewish community, which had a significant presence in Medina at that time. The points of criticism range from the divinisation of Jesus Christ among Christians to the charge against the Jews of killing the prophets (Q 5:70).

The various statements in the Qur'an regarding Christianity and Judaism constitutes the foundation for the ambivalence noted above in dealing with Jews and Christians from an Islamic perspective. This also makes it evident that a contextual approach to the Qur'anic statements is needed to reinforce the potential for promoting peace and to make a differentiated approach to the other religions possible. For, as Oberdorfer and Waldman state, there is a "fundamental ambivalence" (Oberdorfer \& Waldman, 2008, 11) in all religions. But the research into conditions that lead to the activation of one of these ambivalences is more important (ibid., 11f.). Zirker also sees the problem as not lying primarily in the violent statements found in the holy texts, which, in his view, "do not present any theological problem" (Zirker, 1998, 168). What Zirker finds more disturbing, however, is "that certain structures of religious thinking tend a priori towards radical oppositions, even if they are initially relatively open and not fixed on unambiguous consequences of action" (ibid.).

This is a statement that can be endorsed without any reservations from the Muslim perspective and requires an appropriate critical approach to the holy scriptures.

\section{The Personal Perspective: Between Formality and Hypocrisy}

Like every other religion, Islam also contains rules that present the general conditions of faith as such and, among other things, confers a unique identity on its adherents. These rules include, according to the religion in question, various 
life areas of the human being. The observance of these rules is to help believers maintain their relationship to God and thus give meaning to their lives. But, as with every institutionalisation, a kind of formalisation also threatens faith in the process of the development of its own doctrine or in its process of its constitution if the rules, which are originally intended to serve faith, suppress or replace it instead. The parts thus become more important than the whole; formal rituals become more important than ethical principles. This tendency can even undermine the essence of a faith and, to put it mildly, water down the original mission. A tendency against which no faith can be secure, it is one more instance of ambivalence that becomes increasingly manifest in the Islamic context. As a result, both Muslim writers and non-Muslim experts on Islam draw attention to that phenomenon.

Among the important experts on Islam who draw attention to this problem is the Canadian religious studies and Islam scholar Wilfred Cantwell Smith (d. 2000). Smith holds that a meaning shift in the concept of Islam occurred in the $19^{\text {th }}$ century in which the individual character of Islam was equated with the religious system (Smith, 1964, 105). Viewed from a Qur'anic perspective, this is not an obvious move (ibid., 101f.). In his explanations, Smith draws attention to the constant tendency to shift the concept 'Islam' from personal faith or piety towards a religious system. Smith expresses it as follows:

There has been a tendency over the centuries and especially in modern times for the connotation of the word 'Islam' gradually to lose its relationship with God, first by shifting from a personal piety to an ideal religious system, a transcendent pattern, then to an external, mundane religious system, and finally by shifting still further from that religious system to the civilization that was its historical expression. (Smith, 1981, 63f.)

These views have also been increasingly discussed recently by voices within Islam, even if from a different perspective. Mouhanad Khorchide is one of those voices, and in his publications, he has attempted to draw attention to this phenomenon. In his book on Shariah, which he claims provides a non-legalistic approach to the Shariah for the laity (Khorchide, 2013, 22), he writes:

To purify the heart is not primarily an intellectual task but rather an emotional and spiritual one. A legalistic understanding of Islam masks the work of purifying the heart. The heart should be enabled to recognise the beautiful, the human, and to distinguish them from the ugly, the inhuman. But if religiosity is defined as adhering to legalistic statements, not only has the heart shifted to the background but human freedom as well and thus an authentic moral attitude in which morality is determined from within as a commitment. If good actions are directed from outside one, if I also, for example, help someone because I am told to, I have no inner morality. I help because I must help, not because I want to help. (Ibid., 17) 
Without going into detail, this statement shows in our context that the meaning shift in Islam towards legalism can also be observed by Muslims themselves and is felt to be a deviation from Islam's original intention. The tendency here to keep to the wording of the text, as already mentioned in this essay, plays an important role in the development of a formalised approach to faith. This rather legalistic way of understanding faith has led to, among other things, greater value being attributed to religious rituals or external acts than to the ethical principles that are also embedded in the Islamic sources. Such a legalistic reading almost dissolves the connection between the religious rituals and the ethical principles. The dissolution of the existential relation between the rituals and a moralistic attitude often leads, for example, to the same person performing the five prayers and slandering others at the same time, even though this represents what the Qur'an also sees as a paradox. According to the Qur'an, prayer keeps the person from hateful deeds ( $Q$ 29:45), and gossip is so abhorrent that the Qur'an compares it to the consumption of human flesh ( $Q$ 49:12). To prevent religion from turning into something without content, the Qur'an constantly attempts to draw attention to this phenomenon. One of the important chapters (sura) to do this is the $107^{\text {th }}$, where we read:

HAST THOU ever considered (the kind of man) who gives the lie to all moral law? Behold, it is this (kind of man) that thrusts the orphan away, and feels no urge to feed the needy. Woe, then, unto those praying ones whose hearts from their prayer are remote - those who want only to be seen and praised, and, withal, deny all assistance (to their fellowmen)! (Q 107:1-7)

This short Meccan sura points to a kind of formalisation of religion in which prayer is turned into a show and, understandably, cannot produce any virtues that could serve humanity and thus God. The focus on the formal, literal, or legalistic aspect of religion without the inclusion of values like love, justice, mercy, sustainability, reconciliation, etc. leads inevitably to a pseudo-religiosity that stays on the surface or a kind of religiosity without content. Given that a religiosity limited to external rituals is much easier to master than one focused on internal values, the majority often prefer it on practical grounds. That is why spirituality often remains in the background and the normative moves to the foreground.

Thus, this ambivalence between the external and the internal side of religion is one that very much stamps contemporary everyday Muslim life and is also decisively responsible for differences within the Islamic community. That is why people who perform all the rituals can still take the lives of innocent people while calling on God and hoping to be rewarded in the afterlife. 


\section{Conclusion}

The analysis of some of these ambivalences shows that there are always different, even contradictory, approaches to religion, and that will probably be the case in the future as well. That is why one needs to be aware of these ambivalences and thus understand oneself as a seeker and not as a possessor of truth. Even if believers should assume that God is the absolute and only truth (for them), that does not change the fact that human beings themselves are limited and never able to possess absolute truth. Faith does not exist in the claim to possess the truth but in the knowledge of one's own finiteness.

In this connection, the statement by Max Born concerning our alleged possession of truth is very striking. But in our context, his statement also needs to be understood with respect to religions. Born writes:

I believe that ideas like absolute correctness, absolute precision, definitive truth, etc. are fantasies that should not be admitted to any science.... This easing of our thinking seems to me to be the greatest blessing that contemporary science has brought us. But belief in a single truth and to be its possessor is the deepest root of all evil in the world. (Born, 1965, 183) 
